В.В. Коваль

Генеральний штаб Збройних Сил України, Київ

\title{
СУКУПНІСТЬ ОСНОВНИХ ПРИНЦИПІВ ВИЗНАЧЕННЯ РАЦІОНАЛЬНОГО СКЛАДУ СИЛ I ЗАСОБІВ ДЛЯ МАСКУВАННЯ ТА ІМІТАЦІЇ ВІЙСЬКОВИХ ОБ'ЄКТІВ ВІД ТЕХНІЧНИХ ЗАСОБІВ ПОВІТРЯНОЇ РОЗВІДКИ ТА НАВЕДЕННЯ ЗБРОЇ ПРОТИВНИКА
}

Подальший розвиток теорії захисту військових об'єктів від технічних засобів повітряної розвідки та наведення зброї (ТЗПР) противника, особливо визначення завдань иъього прочесу в операціях (бойових діях) та оиінювання ефективності їх виконання, неможливі без формулювання відповідних принципів визначення раціонального складу сил і засобів для маскування та імітації військових об'єктів від ТЗРНЗ противника. У статті сформульовано основні принщипи визначення раџіонального складу сил і засобів для маскування та імітації військових об'єктів від ТЗПР противника, які грунтуються на загальних принщипах створення оперативно-стратегічних (оперативних) угруповань військ (сил), встановлених закономірностях подальшого розвитку сил захисту військових об'єктів від засобів повітряного нападу противника, особливостях застосування сил і засобів маскування в сучасних операџіях (бойових діях), розкрито їх зміст, проведено класифікацію та систематизацію.

Ключові слова: маскування, імітація, технічні засоби повітряної розвідки та наведення зброї, раціональний склад сил $і$ засобів.

\section{Вступ}

Постановка проблеми. Різноманітність видів засобів повітряного нападу (ЗПН) противника, можливі масштаби та ефективність їх застосування в операціях (бойових діях), комплексування засобів розвідки, ураження та автоматизованого управління вимагають чіткої організації заходів захисту військових об'єктів для підвищення їх живучості. У даному процесі важливу роль буде відігравати ретельна організація відповідних заходів маскування та імітації військових об'єктів від технічних засобів повітряної розвідки та наведення зброї (ТЗПРНЗ) противника.

Подальший розвиток теорії захисту військових об'єктів від ТЗПРНЗ противника, особливо визначення завдань цього процесу в операціях (бойових діях) та оцінювання ефективності їх виконання, неможливі без формулювання відповідних принципів визначення раціонального складу сил і засобів для маскування та імітації військових об'єктів від ТЗРНЗ противника. Такі принципи є складовою частиною відповідного процесу підготовки держави до оборони, ведення операцій (бойових дій) [1-3] та основою для визначення раціонального складу сил і засобів для маскування та імітації військових об'єктів від ТЗРНЗ противника в операціях (бойових діях) [4-8].

Сьогодні теоретичні основи захисту військових об'єктів від ТЗРНЗ противника розроблені недостатньо повно. Наразі не сформовано сукупність основних принципів, яких необхідно дотримуватись для визначення раціонального складу сил і засобів для маскування та імітації військових об'єктів від ТЗРНЗ противника в операціях (бойових діях). У таких умовах виникає нагальна потреба уточнити існуючі, сформулювати нові, систематизувати та класифікувати принципи визначення раціонального складу сил і засобів для виконання завдань маскування та імітації військових об'єктів від ТЗРНЗ противника в операціях (бойових діях), що і обумовлює актуальність даної статті.

Аналіз останніх досліджень і публікацій. Питанням дослідження принципів побудови організаційних структур військ та систем управління ними, маскування та імітації військових об'єктів від ТЗРНЗ противника присвячена певна кількість наукових робіт [1; 9-15]. Дані роботи присвячені класифікації та змісту принципів стратегічного управління підготовкою держави до оборони [1], обгрунтуванню модульного принципу формування організаційних структур та принципів структурної побудови міжвидових угруповань військ Збройних Сил України [9], розкриттю загальносистемних принципів побудови автоматизованої системи управління ракетних військ та артилерії [10], аналізу відомих принципів воєнного мистецтва та принципів військового управління [11], формулюванню основних принципів розвитку організаційних структур загальновійськових об'єднань, з’єднань і частин Сухопутних військ [12].

Проведений аналіз наведених джерел дозволяє зробити висновок, що сформульовані напрацювання не повною мірою дозволяють сформувати сукуп- 
ність принципів, необхідних для визначення раціонального складу сил і засобів для виконання завдань маскування та імітації військових об'єктів від ТЗРНЗ противника в операціях (бойових діях).

Тому метою статті є формулювання, класифікація та систематизація принципів визначення раціонального складу сил і засобів для виконання завдань маскування та імітації військових об'єктів від ТЗРНЗ противника в операціях (бойових діях).

\section{Виклад основного матеріалу}

Створення ефективних систем, здатних ефективно протидіяти ЗПН противника в операціях (бойових діях), є одним із головних завдань держави. Такий процес повинен проводитися з обов'язковим урахуванням розвитку тенденцій збройної боротьби, a саме [13-14]: розширення простору і підвищення динамізму ведення збройної боротьби; підвищення впливу наслідків боротьби у повітрі на остаточний результат воєнного конфлікту; значне збільшення можливостей новітніх систем озброєння, зокрема високоточної зброї, ТЗПРНЗ; одночасне ураження військ (сил), інфраструктури на всій території противника зі зміною пріоритетів у збройній боротьбі в бік зниження його воєнно-економічного потенціалу; зменшення часових параметрів активної фази воєнного конфлікту.

За таких умов забезпечення надійного прикриття військ і об'єктів країни від ударів з повітря $є$ пріоритетним завданням, яке має виконуватися в процесі реформування та розвитку Збройних Сил України.

Досвід локальних війн та збройних конфліктів останнього десятиріччя, застосування Збройних Сил України на сході нашої країни переконливо свідчить, що сили й засоби повітряного нападу здатні виконувати як оперативно-тактичні, так і стратегічні завдання. Це обумовлює тенденцію підвищення значення ходу та наслідків збройної боротьби в повітряному просторі для досягнення успіху не тільки в окремих операціях, але й сучасному воєнному конфлікті в цілому.

У таких умовах розбудова Збройних Сил України неможлива без формування сукупності обгрунтованих та взаємопов'язаних заходів щодо створення надійної системи захисту військових об'єктів від ударів ЗПН противника, у тому числі визначення раціонального складу сил і засобів маскування та імітації військових об'єктів від ТЗПРНЗ противника.

Такі заходи відображають основу воєнної діяльності і об’єкт пізнання воєнної науки стосовно будівництва Збройних Сил та формують базове методологічне поняття “організаційне будівництво Збройних Сил” [2-3].

У процесі організаційного будівництва Збройних Сил України важливе місце має визначення ра- ціонального складу сил і засобів для маскування та імітації військових об'єктів від ТЗРНЗ противника, яке повинно здійснюватися на основі знання законів і закономірностей, а також набутого досвіду в результаті практичної діяльності органів військового управління та військ (сил).

За результатом такого досвіду формуються відповідні принципи, які являють собою загальні науково обгрунтовані положення, правила, рекомендації щодо дій органів військового управління та військ (сил) для досягнення визначеної мети [2-3].

Поняття “принцип” близьке за змістом до понять “закон” i “закономірність”. Їх близькість полягає в тому, що всі вони відображають суттєві, необхідні, неодноразово виявлені зв'язки, відношення дійсності. Разом з цим принцип не лише відбиває об'єктивно існуючий зв'язок, але й визначає, як слід діяти в конкретних умовах для досягнення тієї чи іншої мети. В ньому виражається єдність об'єктивного і суб'єктивного.

Принципи визначення раціонального складу сил і засобів для виконання тих чи інших завдань формуються з урахуванням законів війни, законів збройної боротьби, закономірностей створення військових систем, принципів воєнного мистецтва, загальних принципів побудови систем військового призначення.

3 урахуванням викладених у [2; 9; 12] загальних принципів створення оперативно-стратегічних (оперативних) угруповань військ (сил) можливо сформулювати загальні системні принципи визначення раціонального складу сил і засобів для маскування та імітації військових об'єктів від ТЗПРНЗ противника, а саме:

- комплексний характер визначення раціонального складу сил і засобів маскування та імітації військових об'єктів від ТЗПРНЗ противника;

- відповідність складу сил і засобів маскування та імітації військових об’єктів від ТЗПРНЗ противника складу і структури угруповання військ (сил), що прикриваються від ударів ЗПН противника;

- уніфікація структури і стандартизація засобів сил i засобів маскування та імітації військових об'єктів від ТЗПРНЗ противника формуваннями видів та родів військ (сил) ЗС України;

- поетапне удосконалення складу сил і засобів маскування та імітації військових об'єктів без порушення функціонування системи захисту військ та об'єктів від ударів ЗПН противника;

- своєчасне удосконалення складу сил і засобів маскування та імітації військових об'єктів при змінюванні структури і складу ЗС України;

- інтеграція складу сил і засобів маскування та імітації військових об'єктів від ТЗПРНЗ противника у систему захисту військ та об'єктів від ударів ЗПН противника. 
Під час визначення раціонального складу сил і засобів для маскування та імітації військових об'єктів від ТЗПРНЗ противника необхідно також враховувати основні закономірності подальшого розвитку сил захисту військових об'єктів від ЗПН противника [13-14], а саме:

- залежність організаційних структур сил захисту військових об'єктів від ЗПН противника від структури оперативних угруповань військ;

- відповідність організаційних структур сил захисту військових об'єктів від ЗПН противника різноманітним видам бойових дій;

- відповідність організаційних структур сил захисту військових об’єктів від ЗПН противника завданням, що виконуються;

- дотримання раціонального співвідношення сил і засобів захисту військових об'єктів від ЗПН противника;

- залежність структури системи захисту військових об’єктів від ЗПН противника від сил і засобів, що виділяються для їх формування.

3 урахуванням вказаних закономірностей можливо сформулювати загальні приниипи формування складу сил і засобів маскування та імітації військових об’єктів від ТЗПРНЗ противника, а саме:

ефективності - раціональне співвідношенні між отриманим ефектом під час захисту військових об'єктів від ТЗПРНЗ противника та витратами на формування складу сил і засобів маскування та імітації військових об'єктів від ТЗПРНЗ противника. При цьому, проводиться аналіз можливих варіантів формування сил і засобів маскування та імітації, за результатами якого обирається варіант $з$ найменшими витратами;

достатності - визначена кількість сил і засобів маскування та імітації військових об'єктів від ТЗПРНЗ противника не перевищує кількості, необхідної для гарантованого виконання визначених завдань в операції (бойових діях);

збалансованості - сформований склад сил і засобів маскування та імітації військових об'єктів від ТЗПРНЗ противника забезпечує необхідну ефективність захисту в умовах виділених ресурсів.

Відповідно до системного підходу основним принципом організаційного будівництва Збройних Сил є забезпечення відповідності їх складу завданням, що на них покладаються у мирний і воєнний час з урахуванням існуючих економічних можливостей держави [3; 7].

Результати локальних війн та збройних конфліктів сучасності, досвід застосування Збройних Сил України на сході нашої держави переконливо свідчать, що складність умов обстановки, яка створюється під час застосування противником ТЗПРНЗ противника, викликає потребу дотримання певних базових принципів маскування та імітації військо- вих об'єктів.

Базові принципи маскування та імітації військових об'єктів, як і принципи застосування будьяких засобів збройної боротьби, відображають певні закони та закономірності ведення операцій (бойових дій) та, насамперед, обумовленні факторами, які впливають на їх результат.

Основним фактором, який визначає результат вирішення як часткових, так і основних завдань військ (сил) в операціях (бойових діях), є противник. Від складу його сил і засобів, положення, стану, можливостей, характеру дій залежить зміст бойових завдань та обсяг завдань 3 маскування та імітації військових об'єктів. Сьогодні на озброєнні збройних сил країн, що межують з Україною, знаходяться досконалі ТЗПРНЗ, які використовують практично весь освоєний на сучасному етапі розвитку науки $\mathrm{i}$ техніки діапазон електромагнітних хвиль.

Це положення, а також особливості застосування ТЗПРНЗ противника в операціях (бойових діях) обумовлюють доцільність обов'язкового урахування під час визначення раціонального складу сил і засобів для маскування та імітації військових об'єктів таких базових принцииів маскування та імітації військових об’єктів [15] (табл. 1):

- постійна готовність військ до маскування та імітації військових об'єктів від ТЗПРНЗ противника;

- відповідність організації маскування військових об'єктів від ТЗПРНЗ противника визначеним завданням військ (сил) в операціях (бойових діях);

- організація та здійснення заходів маскування та імітації військових об'єктів по єдиному замислу захисту військ та об’єктів від ударів ЗПН противника на підставі прийнятого замислу (плану) операції (бойових дій);

- надійність маскування та імітації військових об'єктів від ТЗПРНЗ противника;

- безперервність протидії ТЗПРНЗ противника;

- зосередження основних зусиль маскування та імітації військових об'єктів від ТЗПРНЗ противника на головному напряму та у визначений час;

- вибіркове застосування сил та засобів маскування та імітації для маскування найбільш важливих дійсних військових об'єктів та створення хибних об'єктів;

- тверде управління силами та засобами маскування та імітації;

- масштабність застосування сил і засобів маскування та імітації в операції (бойових діях).

Постійна готовність військ для маскування та імітації військових об'єктів від ТЗПРНЗ противника $\epsilon$ основним базовим принципом та досягається комплексом організаційних та технічних заходів, спрямованих на підтримання готовності до дій в умовах широкомасштабного застосування противником ЗПН. 


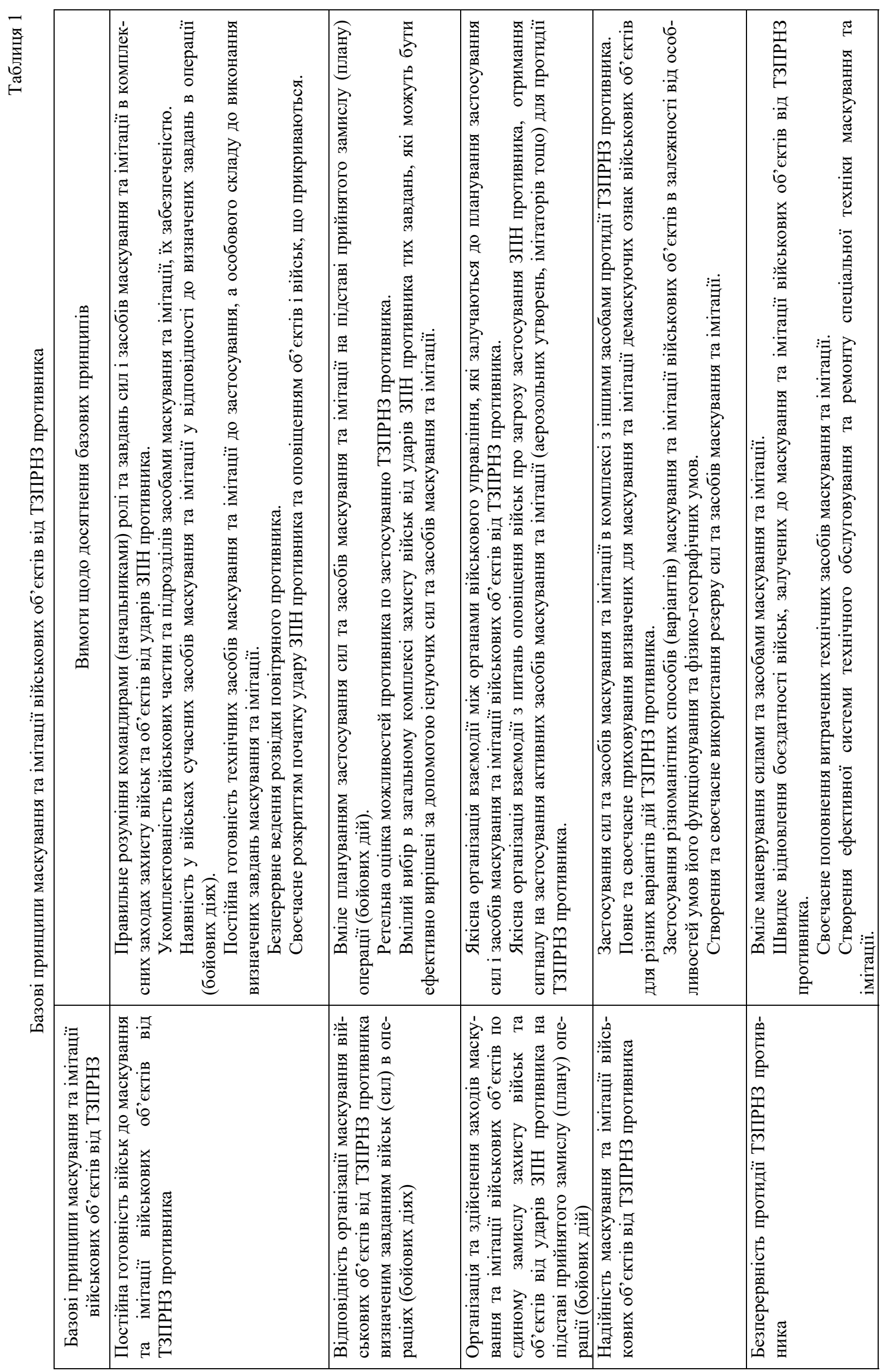


ت્1

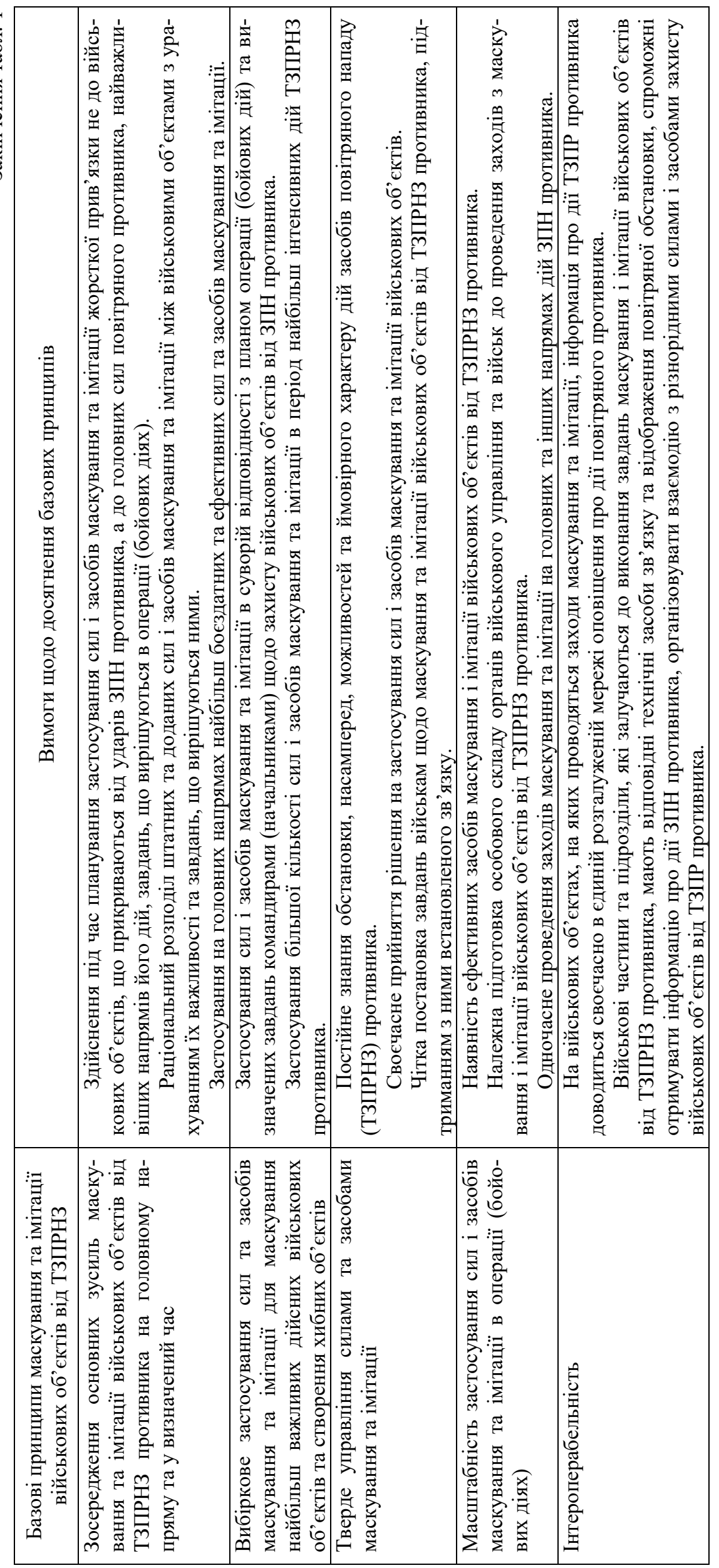

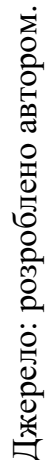


Відповідність організаиії маскування військових об'єктів від ТЗПРНЗ противника визначеним завданням військ (сил) в операціях (бойових діях) обумовлена постійною модернізацією існуючих та створенням нових ТЗПРНЗ, що у свою чергу вимагає нових підходів до визначення ефективних способів маскування та імітації військових об’єктів для підвищення їх живучості та збереження боєздатності військ (сил).

Організачія та здійснення заходів маскування та імітаиії військових об'єктів по єдиному замислу та плану вимагає узгоджувати застосування різноманітних варіантів маскування та імітації військових об'єктів від ТЗРНЗ противника по завданнях, місцю, часу на напрямках дій.

Надійність застосування сил та засобів маскування та імітаиії полягає в зниженні втрат військових об'єктів від ударів ЗПН противника та ймовірності їх виявлення ТЗПРНЗ противника за рахунок комплексування сил і засобів протидії, їх резервування з урахуванням особливостей функціонування військових об'єктів.

Безперервність маскування та імітації військових об'єктів буде вимагати здійснення протидії ТЗПРНЗ противника в будь-яких умовах обстановки.

В умовах широкомасштабного застосування ЗПН неможливо прикривати усі військові об'єкти. Тому, у сучасних умовах значно трансформується сутність принципу зосередження основних зусиль сил $i$ засобів маскування та імітації військових об’єктів від ТЗПРНЗ противника. Під час маскування та імітації необхідно буде здійснювати прив'язку не до військових об'єктів, а до ЗПН, найважливіших напрямів їх дій, завдань, що вирішуються противником в операції (бойових діях). Реалізація вказаного принципу можлива шляхом більш детального прогнозування дій повітряного противника, якісною організацією управління силами і засобами маскування та імітації, створенням розгалуженої мережі автомобільних, залізничних, морських i річкових шляхів та аеродромів для рішучого маневрування військами.

Вибіркове застосування сил та засобів маскування та імітації забезпечує розосередження зусиль ТЗРНЗ противника та сприяє зниженню ефективності ударів ЗПН шляхом застосування більшої кількості сил і засобів маскування та імітації в період найбільш інтенсивних дій противника. Тверде та безперервне управління силами та засобами маскування та імітаиіï досягається постійним знанням обстановки та своєчасним прийняттям рішення на застосування сил і засобів маскування та імітації військових об'єктів від ТЗПРНЗ противника.

Застосування сил та засобів маскування та імітації військових об'єктів дозволяє оперативно та без значних втрат вирішувати широкий спектр завдань щодо захисту військ від ударів ЗПН противника. У сукупності з тим, що сучасні носії ТЗПРНЗ забезпечують ведення розвідки та ураження військових об'єктів на значних відстанях від лінії бойового зіткнення, обумовлює доцільність дотримання принципу масштабності застосування сил $і$ засобів маскування та імітації в операції (бойових діях).

Принцип інтероперабельності вимагає забезпечення сил і засобів необхідною інформацією про дії повітряного противника для одночасного виконання завдань маскування та імітації на значній кількості військових об'єктів стратегічного, оперативного та тактичного рівнів, створення необхідних умов для організації взаємодії між різнорідними силами і засобами захисту військ і об'єктів від ТЗПРНЗ противника.

Зрозуміло, що наведені принципи застосування сил і засобів маскування та імітації є основними, а їх зміст потребує постійного доповнення в залежності від тенденцій подальшого розвитку збройної боротьби.

3 точки зору системного підходу [2; 7; 16] сили і засоби можна розглядати як цілісну ієрархічну складну ергатичну систему військового призначення. Тому під час визначення раціонального складу сил i засобів для маскування та імітації військових об'єктів від ТЗПРНЗ противника необхідно також використовувати структурно-організаичійні принц̧ипи.

3 урахуванням положень, викладених у [17], та особливостей побудови багаторівневої системи захисту військових об'єктів від ударів ЗПН противника можна сформулювати такі основні структурноорганізаційні принципи для визначення раціонального складу сил і засобів для маскування та імітації військових об'єктів:

цілеобумовленості - для досягнення мети захисту військових об'єктів від ТЗПРНЗ противника повинна формуватися належним чином організована сукупність технічних засобів. Загальна мета, яка поставлена силам маскування та імітації військових об’єктів від ТЗПРНЗ противника, повинна визначати відповідні локальні цілі, які, у свою чергу, виступають як засоби досягнення загальної мети. При цьому, локальні цілі повинні відповідати вимогам достатності та необхідності. Відсіювання і вибір потенційних локальних цілей, встановлення відношення порядку між ними дозволяє сформувати впорядковану множину локальних цілей та відповідну програму досягнення загальної мети. Це найважливіший етап визначення раціонального складу сил i засобів для маскування та імітації військових об'єктів від ТЗПРНЗ противника. У процесі функціонування мета може змінюватися. Відповідно до цього повинні змінюватися структура системи захисту від ЗПН противника та способи застосування сил і засобів маскування та імітації військових об’єктів від ТЗПРНЗ противника. Мета - категорія зовнішня 
по відношенню до сил і засобів маскування та імітації військових об’єктів від ТЗПРНЗ противника, вона ставиться їй системою більш високого рівня. Мета повинна бути сформульована таким чином, щоб іiі можна було оцінити (визначити) кількісно;

відносності - одна і та ж сукупність сил і засобів маскування та імітації військових об'єктів від ТЗПРНЗ противника може розглядатися як самостійна складова, так і як складова іншої сукупності сил і засобів захисту військових об'єктів від ЗПН противника. Даний принцип розкриває механізм цілепокладання та обумовлює необхідність під час визначення доцільної структури об'єднання сил і засобів маскування та імітації військових об'єктів від ТЗПРНЗ противника упорядковувати їх за відповідними рівнями;

адаптивності - цілі застосування сил і засобів захисту військових об'єктів від ЗПН противника не $\epsilon$ статичними, жорсткими. Залежно від обстановки, що складається, виникнення нових завдань, зовнішнього середовища й інших факторів вони можуть i повинні змінюватися. При цьому, з урахуванням високої динамічності цілей структура об’єднання сил і засобів маскування та імітації військових об'єктів від ТЗПРНЗ противника повинна бути адаптивною, тобто здатною змінюватися в залежності від цілей та умов функціонування системи. Така зміна може відбуватися шляхом зміни кількості сил і засобів, та зв'язків між ними тощо;

рефлективності - сутність принципу рефлексії полягає в тому, що структура об'єднання сил і засобів маскування та імітації військових об'єктів від ТЗПРНЗ противника та їх склад повинні відповідати діям противника. Для його реалізації необхідно постійно знати стан і тенденції розвитку ЗПН та ТЗПРНЗ противника, тактику їх застосування тощо, а сили маскування та імітації бути спроможними застосовувати ефективні способи та прийоми протидії;

оперативності - адаптивність і конфліктний характер взаємодії сил і засобів захисту військових об'єктів від ЗПН противника приводить до необхідності враховувати фактор часу під час синтезу структури об'єднання сил і засобів маскування та імітації військових об'єктів від ТЗПРНЗ противника;

відповідності організаційної структури об'єднання сил $і$ засобів маскування та імітації завданням захисту військових об'єктів від ЗПН противника - виконання даного принципу генерує чітку організацію взаємодії сил і засобів під час комплексного вирішення завдань маскування та імітації військових об'єктів від ТЗПРНЗ противника.

Ефективний захист військових об'єктів від ударів ЗПН противника можливий за умови удосконалення системи управління силами маскування та імітації в операції (бойових діях). 3 урахуванням положень, викладених у [13; 18], удосконалення системи управління силами маскування та імітації можливе за рахунок побудови мережецентричної системи управління угрупованням військ (сил). Побудова системи мережецентричного управління, насамперед, може бути реалізована шляхом створення горизонтальних зв'язків між пунктами управління через відповідні автоматизовані системи управління. Основні принципи удосконалення системи управління силами маскування та імітації в операції (бойових діях) наведено в табл. 2.

Таблиця 2 Основні принципи удосконалення системи управління силами маскування та імітації в операції (бойових діях)

\begin{tabular}{|c|c|}
\hline Принцип & Зміст принципу \\
\hline $\begin{array}{c}\text { Управління } \\
\text { у єдиному просторі }\end{array}$ & $\begin{array}{l}\text { Створення єдиного інформаційно-комунікаційний простору шляхом об’єднання } \\
\text { розвідувальних та інформаційних мереж, органів і пунктів управління, засобів } \\
\text { захисту військових об’єктів від ударів ЗПН противника }\end{array}$ \\
\hline $\begin{array}{c}\text { Змішаного } \\
\text { управління } \\
\text { за структурою }\end{array}$ & $\begin{array}{l}\text { Використання ієрархічного (централізованого) і неієрархічного управління (за- } \\
\text { стосовуються горизонтальні зв’язки), здійснюється координація дій сил і засобів } \\
\text { захисту військових об’єктів від ударів ЗПН противника }\end{array}$ \\
\hline Сумісності & $\begin{array}{l}\text { Технічне і функціональне сполучення локальних мереж різнорідних сил і засобів } \\
\text { захисту військових об’єктів від ударів ЗПН противника в операційній зоні (райо- } \\
\text { ні бойових дій) }\end{array}$ \\
\hline Відкритої системи & $\begin{array}{l}\text { Можливість нарощування системи управління силами і засобами захисту війсь- } \\
\text { кових об’єктів від ударів ЗПН противника за рахунок підключення нових джерел, } \\
\text { споживачів інформації, засобів їі обробки і зберігання через об'єднану мережу } \\
\text { обміну даними }\end{array}$ \\
\hline Модульності & $\begin{array}{l}\text { Комплекси засобів автоматизації різнорідних сил і засобів захисту військових } \\
\text { об’єктів від ударів ЗПН противника створюються з окремих відносно незалежних } \\
\text { модулів, сполучених технічно, інформаційно і функціонально }\end{array}$ \\
\hline $\begin{array}{l}\text { Розподілення } \\
\text { інформаційних } \\
\text { ресурсів }\end{array}$ & $\begin{array}{l}\text { Розосередження інформації, що обробляється і зберігається з метою забезпечення } \\
\text { функціонування системи управління силами і засобами захисту військових } \\
\text { об'єктів від ударів ЗПН противника під час виходу з ладу одного або декількох } \\
\text { компонентів мережі }\end{array}$ \\
\hline
\end{tabular}

Джерело: розроблено автором. 


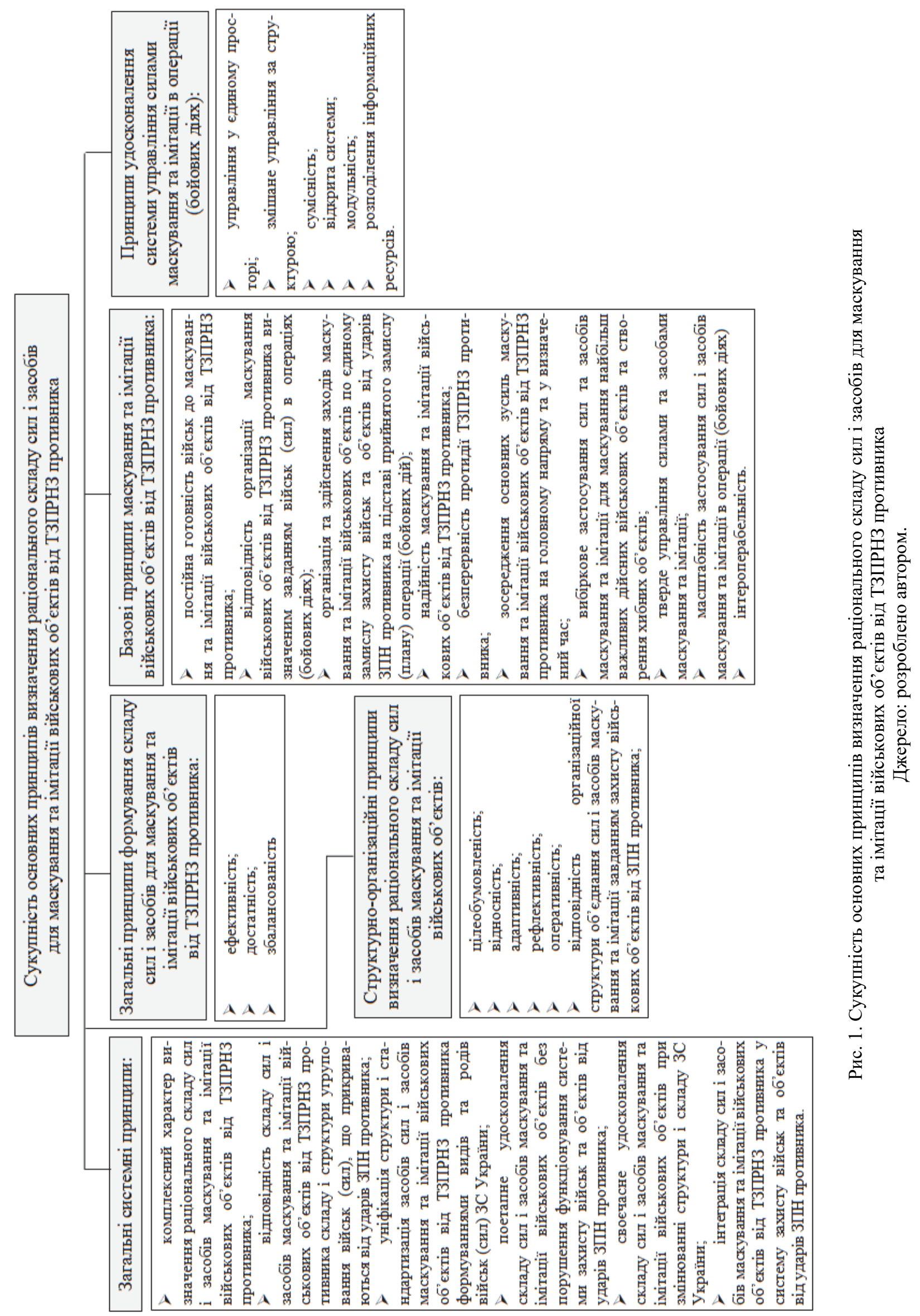




\section{Висновки}

Таким чином, у статті сформульовано основні принципи визначення раціонального складу сил і засобів для маскування та імітації військових об’єктів від ТЗПР противника (рис. 1), які грунтуються на загальних принципах створення оперативно-стратегічних (оперативних) угруповань військ (сил), встановлених закономірностях подальшого розвитку сил захисту військових об'єктів від ЗПН противника, особливостях застосування сил і засобів маскування в сучасних операціях (бойових діях), розкрито їх зміст, проведено класифікацію та систематизацію. Використання удосконаленої сукупності принципів дозволить сформувати раціональний склад сил і засобів з необхідними можливостями для маскування та імітації військових об'єктів від ТЗПР противника. Напрямом подальшого дослідження є обгрунтування сукупності показників і критеріїв для оцінювання ефективності виконання завдань маскування та імітації військових об'єктів від ТЗПР противника.

\section{Список літератури}

1. Лобанов А.А. Принципи стратегічного управління підготовкою держави до оборони [Текст] / А.А. Лобанов, Ю.В. Пунда // Сучасні інформаційні технології у сфері безпеки та оборони. - 2013. - № 1(16). - С. 11-16.

2. Тимошенко Р.І. Загальні методологічні положення воєнно-наукового обгрунтування складу Збройних Сил України на сучасному етапі їх реформування / Р.І. Тимошенко, О.М. Загорка // Наука і оборона. - 2014. - № 1. - С. 43-48.

3. Організаційне будівництво Повітряних Сил Збройних Сил України: методичні аспекти / Ю.А. Байдак, О.М. Загорка, В.В. Гамора, В.В. Коваль // Наука і оборона. - 2014. - № 3. - С. 17-22.

4. Руснак І.С. Воєнна безпека України у світлі реформування сектора безпеки і оборони / I.С. Руснак // Наука і оборона. - 2015. - № 2. - С. 9-22.

5. Методологічні засади обгрунтування раціональних форм та способів застосування угруповань військ (сил): Воєнно-теоретична праця / В.Г. Радецький, І.С. Руснак, О.М. Загорка та ін.; за заг. ред. С.О. Кириченка. - К.: НАОУ, 2007. $-288 \mathrm{c}$.

6. Тараканов К.В. Математика и вооруженная борьба / К.В. Тараканов. - М.: Воениздат, 1974. - 240 с.

7. Руснак І.С. Розвиток методологічних положень обгрунтування заходів організаційного будівництва (реформування) Повітряних Сил / І.С. Руснак, О.М. Загорка // Наука і оборона. - 2010. - № 1. - С. 6-12.

8. Телелим В.М. Обгрунтування раціональної структури органів військового управління: методичний аспект / В.М. Телелим, Р.І. Тимошенко, О.М. Загорка // Наука і оборона. - 2013. - № 1. - С. 45-50.

9. Телелим В.М. Модульний принцип створення міжвидових угруповань військ: проблеми запровадження та шляхи їх розв'язання [Текст] / В.М. Телелим, Д.П. Музиченко, Ю.В. Пунда // Наука і оборона. - 2014. - № 2. - С. 20-26.

10. Аналіз стану та основні принципи побудови АСУ РВіА / В.І. Грабчак, С.П. Латін, О.М. Мелешко, В.О. Овчінніков // Збірник наукових праць Харківського національного університету Повітряних Сил. - 2007. - № 3(15). - С. 85-89.

11. Сбітнєв А.І. Принципи військового управління та військового мистецтва - базис сучасної науки [Текст] / А.І. Сбітнєв // Сучасні інформаційні технології у сфері безпеки та оборони. - 2008. - № 1(1). - С. $42-49$.

12. Гирин А.В. Организационно-штатная структура объединений, соединений и частей Сухопутных войск. Глава 1. Организация общевойсковых объединений, соединений, частей и подразделений Сухопутных войск [Електронний ресурс] / А.В. Гирин. - Режим доступу: http://samlib.ru/a/aleksandr_walerxewich_girin/struktura_glava_1.shtml. - Haзва 3 екрану.

13. Ярош С.П. Теоретичні основи побудови та застосування розвідувально-управляючих інформаційних систем протиповітряної оборони: монографія / С.П.Ярош, за ред. І.О. Кириченка. - Х.:ХУПС, 2012.- 512 с.

14. Теорія і практика боротьби з малорозмірними низьколітними цілями (оцінка можливостей, тенденції розвитку засобів протиповітряної оборони): монографія / І.С. Романченко, О.М. Загорка, С.Г. Бутенко, О.В. Дейнега. - Житомир: "Полісся", 2011. - 344 с.

15. Петрушенко М.М. Застосування аерозольних утворень для захисту військових об'єктів від ударів літаків тактичної авіації / М.М. Петрушенко, О.М. Загорка, Г.В. Пєвцов, В.В. Коваль, Г.А. Кучук; за ред. М.М. Петрушенка. Винниця - Харків: Командування Повітряних Сил Збройних Сил України; Харківський університет Повітряних Сил ім.І. Кожедуба, 2012. -128 с.

16. Телелим В.М. Планування сил для виконання бойових завдань у “гібридній війні” [Текст] / В.М. Телелим, Д.П. Музиченко, Ю.В. Пунда // Наука і оборона. - 2014. - № 3. - С. 30-35.

17. Герасимов В.І. Проектування організаційних структур: методи і алгоритми / В.І. Герасимов, О.А. Рабчук. - К.: БФ “Миротоворець”, 2000. - 206 с.

18. Особливості та принципи побудови мережецентричної системи управління угруповання військ (сил) / О.М. Загорка, В.В. Коваль, В.В. Тюрін, В.Г. Малюга, І.О. Загорка // Збірник наукових праць Харківського національного університету Повітряних Сил. - 2016. - № 3(48). - С. 7-11. 
Відомості про автора:

Коваль Володимир Валерійович

кандидат військових наук старший науковий співробітник начальник Воєнно-наукового управління

Генерального штабу Збройних Сил України, Київ, Україна

https://orcid.org/0000-0002-6209-6779

\section{Information about the author:}

Volodymyr Koval

Candidate of Military Sciences Senior Research

Deputy Chief of Military Science Division

of General Staff of the Armed Forces of Ukraine,

Kyiv, Ukraine

https://orcid.org/0000-0002-6209-6779

\title{
СОВОКУПНОСТЬ ОСНОВНЫХ ПРИНЦИПОВ ОПРЕДЕЛЕНИЯ РАЦИОНАЛЬНОГО СОСТАВА СИЛ И СРЕДСТВ ДЛЯ МАСКИРОВКИ И ИМИТАЦИИ ВОЕННЫХ ОБЪЕКТОВ ОТ ТЕХНИЧЕСКИХ СРЕДСТВ ВОЗДУШНОЙ РАЗВЕДКИ И НАВЕДЕНИЯ ОРУЖИЯ ПРОТИВНИКА
}

\author{
В.В. Коваль
}

Дальнейтее развитие теории защиты военных объектов от технических средств воздушной разведки и наведения оружсия противника, особенно определение задач этого процесса в операциях (боевых действиях) и оценки эффективности их выполнения, невозможны без формулировки соответствующих принципов определения рационального состава сил и средств для маскировки и имитации военных объектов. В статье сформулированы основные принципь определения рационального состава сил и средств для маскировки и имитачии военных объектов, основанные на общих приничипах создания оперативно-стратегических (оперативных) группировок войск (сил), установленных закономерностях дальнейшего развития сил защиты военных объектов от средств воздушного нападения противника, особенностях использования сил и средств маскировки в современных операциях (боевых действиях), раскрыто их содержание, проведено классификачию и систематизацию.

Ключевые слова: маскировка, имитация, технические средства воздушной разведки и наведения оружия, рациональный состав сил и средств.

\section{SET OF MAIN PRINCIPLES FOR DETERMINING THE RATIONAL COMPOSITION OF FORCES} AND MEANS FOR CAMOUFLAGE AND IMITATION OF MILITARY FACILITIES FROM TECHNICAL MEANS OF AIR RECONNAISSANCE AND GUIDANCE OF WEAPONS OF THE ENEMY

\section{Koval}

Further development of the theory of protection of military facilities from technical means of air reconnaissance and guidance of weapons of the enemy, especially defining the tasks of this process in operations (combat operations) and assessing the effectiveness of their implementation, is impossible without formulating appropriate principles for determining the rational composition of forces and means for camouflage and imitation of military objects from the enemy's technical means of air reconnaissance. The article formulates the main principles of determining the rational composition of forces and facilities for camouflage and imitation of military facilities from enemy technical means of air reconnaissance, which are based on the general principles of creating operational and strategic (operational) groups of troops (forces), established patterns of further development of military defense forces from the means of air attack of the enemy, the features of the use of forces and means of camouflage in modern operations (combat operations), their content is revealed, classification and systematization are carried out. It is shown that

- features of the use of enemy technical means of air reconnaissance and guidance of weapons in operations (combat operations) necessitate consideration when determining the rational composition of forces and means for camouflage and imitation of military objects;

- effective protection of military facilities from enemy is possible under the condition of improving the control system of camouflage forces and simulation in operations (combat operations);

- improving the control system of camouflage and imitation forces is possible by building a network-centric control system for groups of troops (forces). The construction of a network-centric control system, first of all, can be realized by creating horizontal connections between control points through appropriate automated control systems.

Keywords: camouflage, imitation, technical means of air reconnaissance and guidance of weapons, rational composition of forces and means. 